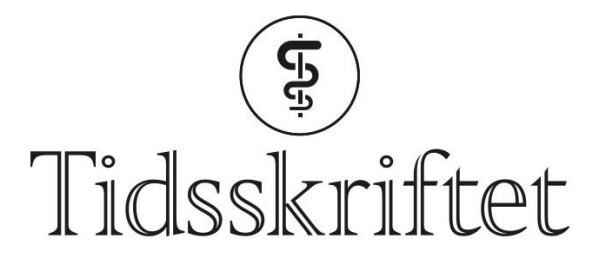

DEN NORSKE LEGEFORENING

\title{
Protonpumpehemmere uten effekt mot hoste
}

FRA ANDRE TIDSSKRIFTER

KETIL SLAGSTAD

Tidsskriftet

Protonpumpehemmere har ingen effekt mot kremting, hoste og opplevelsen av å ha et fremmedlegeme i halsen. Dette viser en randomisert placebokontrollert studie.

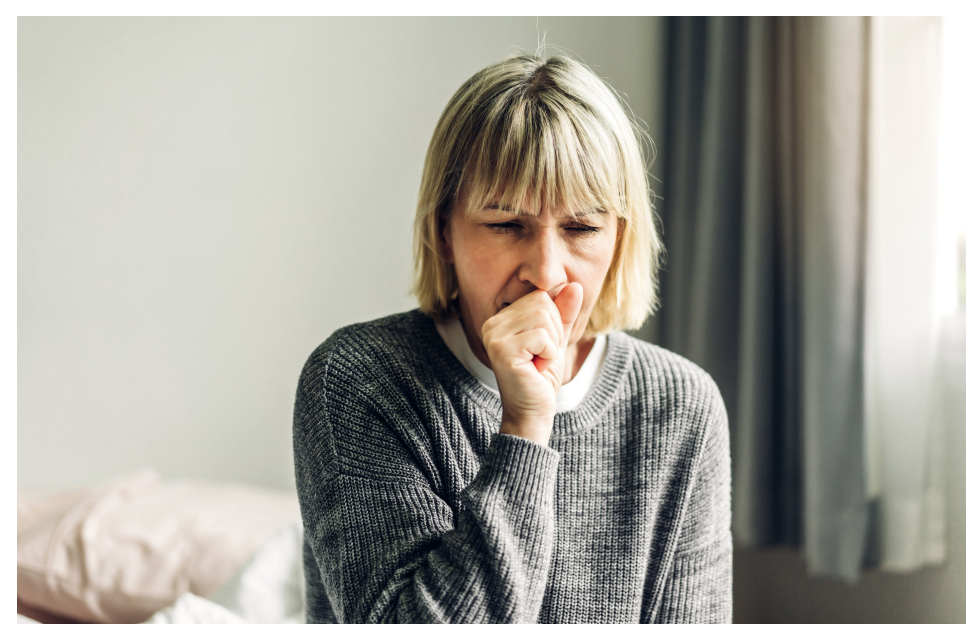

Illustrasjonsfoto: arto_canon/iStock

Vedvarende plager fra munn og svelg, slik som heshet, globusfølelse, kremting, hoste og slimplager, er vanlig hos pasienter i allmennpraksis. Det har vært reist spørsmål om slike plager kan ha sammenheng med gastroøsofageal refluks, og om behandling med protonpumpehemmere kan ha effekt.

I en ny studie publisert i tidsskriftet The BMJ, ble rundt 350 pasienter som var henvist til ørenese-hals-leger pga. uttalte og vedvarende plager fra munn og svelg, randomisert til enten behandling med lansoprazol eller placebo i 16 uker (1). Symptomene avtok i begge gruppene, men det var ingen signifikant forskjell mellom gruppene, verken etter 16 ukers behandling (refluksskår 17,4 versus 15,6; p = o,096) eller ved oppfølgingen ett år senere. Snarere var det en trend til at protonpumpehemmere forverret plagene $(p=0,06)$.

- Dette er en viktig og godt designet studie som forhåpentligvis kan føre til færre unødvendige forskrivninger av protonpumpehemmere, sier May-Lill Johansen, som er spesialist i allmennmedisin og førsteamanuensis ved UiT - Norges arktiske universitet.

- Mer enn hver tiende nordmann bruker slike legemidler, mange på usikker indikasjon, og bivirkningene kan være alvorlige, spesielt ved langvarig bruk. Som allmennlege overrasker 
det meg ikke at protonpumpehemmere er uten effekt mot plager som svelgvansker, klump i halsen, heshet, kremting eller hoste. Slik behandling er da heller ikke anbefalt i norske retningslinjer, påpeker Johansen, som mener at forslaget i Norsk Elektronisk Legehåndbok (NEL) om prøvebehandling med protonpumpehemmere ved kronisk hoste bør gjøres om.

- Forfatterne av denne studien drøfter ikke muligheten for spontanbedring over tid uten behandling, men konkluderer med at placeboeffekten kan ha vært undervurdert for pasienter med disse plagene. Det er derfor grunn til å diskutere hvordan man kan oppnå en slik effekt uten å forskrive medikamenter, sier Johansen.

\section{LITTERATUR:}

1. O'Hara J, Stocken DD, Watson GC et al. Use of proton pump inhibitors to treat persistent throat symptoms: multicentre, double blind, randomised, placebo controlled trial. BMJ 2021; 372: m4903. [PubMed][CrossRef]

Publisert: 22. mars 2021. Tidsskr Nor Legeforen. DOI: 10.4045/tidsskr.21.0046

(C) Tidsskrift for Den norske legeforening 2020. Lastet ned fra tidsskriftet.no 